\title{
Consanguinity and perinatal medicine - the berlin perspective
}

\author{
Rolf Becker
}

\author{
From International Conference on Human Genetics and 39th Annual Meeting of the Indian Society of \\ Human Genetics (ISHG) \\ Ahmadabad, India. 23-25 January 2013
}

The present study was conducted to assess the impact of consanguinity on the prevalence of major anomalies in a prenatal study group of Berlin/Germany.

Over a time-span of 19 years (1993-2011), 34,900 fetuses were examined by prenatal sonography. In 659 cases $(1.9 \%)$ the parents were consanguineous, with $45.2 \%$ related as first cousins $(F=0.0625)$ and $54.8 \%$ beyond first cousins $(F<0.0625)$. Detailed information on the pregnancy outcome of 31,145 fetuses was retrieved either through direct report by families or by active inquiry of patients or their physicians, 555 of these fetuses $(1.8 \%)$ had consanguineous parentage.

The prevalence of major anomalies among fetuses with non-consanguineous parents was $2.8 \%(863 / 30,590)$. By comparison, in the sub-group of fetuses with consanguineous parentage the prevalence was $11.0 \%(61 / 555$ fetuses). Within the consanguineous sub-group a causal association between fetal anomaly and consanguinity was assessed as probable in $6.5 \%(36 / 555)$ of cases, as possible in a further $3.4 \%(19 / 555)$ of cases, and as improbable in $1.1 \%(6 / 555)$ of the diagnosed anomalies.

The data indicate that the prevalence of major fetal anomalies associated with consanguinity was approximately eight percentage points higher than in non-consanguineous offspring. As a proportion of these anomalies result either in intrauterine death or medical termination of pregnancy, the prevalence of consanguinity-associated defects diagnosed post-birth is equivalently lower, thus under-estimating the overall adverse effect of intra-familial marriage on fetal and neonatal well-being.

Published: 21 January 2014

Correspondence: bedaktari@t-online.de

Centre for Prenatal Diagnosis and Human Genetics, Berlin, Germany
doi:10.1186/1755-8166-7-S1-I51

Cite this article as: Becker: Consanguinity and perinatal medicine - the berlin perspective. Molecular Cytogenetics 2014 7(Suppl 1):151.
Submit your next manuscript to BioMed Central and take full advantage of:

- Convenient online submission

- Thorough peer review

- No space constraints or color figure charges

- Immediate publication on acceptance

- Inclusion in PubMed, CAS, Scopus and Google Scholar

- Research which is freely available for redistribution
() Biomed Central

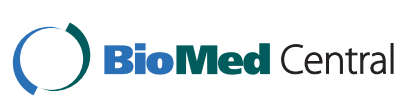

C 2014 Becker; licensee BioMed Central Ltd. This is an Open Access article distributed under the terms of the Creative Commons Attribution License (http://creativecommons.org/licenses/by/2.0), which permits unrestricted use, distribution, and reproduction in any medium, provided the original work is properly cited. The Creative Commons Public Domain Dedication waiver (http:// creativecommons.org/publicdomain/zero/1.0/) applies to the data made available in this article, unless otherwise stated. 